\title{
Anti-diabetic and Antidyslipidemic Activities of Entandrophargma Cylindricum Extract on Streptozotocin- Induced Diabetic Rats
}

\author{
Elizabeth A. Balogun ${ }^{1}$, Samuel D. Ayeni ${ }^{1}$, Al-Ameen O. Otolorin ${ }^{1}$, Damilare E. Rotimi ${ }^{2, *}$ (DD \\ 1 Department of Biochemistry, University of Ilorin, Kwara State, Nigeria \\ 2 Department of Biochemistry, Landmark University, Omu Aran, Kwara State, Nigeria \\ * Correspondence: rotimidamilare1@gmail.com (D.E.R.);
}

Scopus Author ID: 57202368861

Received: 1.02.2021; Revised: 2.03.2021; Accepted: 4.03.2021; Published: 8.03.2021

\begin{abstract}
This study aims to validate the anti-diabetic and antidyslipidemic activities of aqueous extract of Entandrophargma cylindricum stem on streptozotocin-induced diabetic rats. Thirty healthy male Albino rats $(190 \pm 10 \mathrm{~g})$ were grouped into 6 groups of 5 each: group A (control) rats were not induced with diabetes; group B (diabetic treated with Metformin $100 \mathrm{mg} / \mathrm{kg}$ ); group C (diabetic untreated); group D (diabetic treated with Entandrophargma cylindricum extract $50 \mathrm{mg} / \mathrm{kg}$ ); group E (diabetic treated with Entandrophargma cylindricum extract $100 \mathrm{mg} / \mathrm{kg}$ ) and group F (diabetic treated with Entandrophargma cylindricum extract $200 \mathrm{mg} / \mathrm{kg}$ ). Fasting blood glucose concentration and glucose tolerance response increased after 7 days but was reversed near normal on day 14, day 21 . Hexokinase activity significantly $(p<0.05)$ increase in the metformin and $200 \mathrm{mg} / \mathrm{kg}$ bw. However, plasma high-density lipoprotein concentration, plasma insulin concentration, and hepatic glycogen level decreased in the untreated group, 50 and $100 \mathrm{mg} / \mathrm{kg}$ bw. Aqueous extract of E. cylindricum stem bark possesses significant anti-diabetic and antidyslipidemic activity in diabetic rats.
\end{abstract}

Keywords: anti-diabetic; Entandrophargma cylindricum; diabetes mellitus; glucose tolerance; antidyslipidemic.

(C) 2021 by the authors. This article is an open-access article distributed under the terms and conditions of the Creative Commons Attribution (CC BY) license (https://creativecommons.org/licenses/by/4.0/).

\section{Introduction}

Diabetes mellitus (DM) is a metabolic derangement characterized by abnormal blood sugar level (hyperglycemia) as a result of deficiencies in the secretion of insulin, insulin action (sensitivity), or both [1]. The hallmark of diabetes is elevated glucose levels and reduced glucose tolerance. Common DM symptoms include frequent urination (polyuria), increased thirst (polydipsia), and increased hunger (polyphagia) [2]. DM is prevalent among patients with hypertension, atherosclerosis, and cardiomyopathy. DM has been reported to have the most comorbid condition in hypertensive patients [3]. Prolonged diabetes is accompanied by organ dysfunction and failure, neuropathy, retinopathy, cataracts, ulcers, loss of body weight, and sexual inadequacies [4]. The synthetic drugs currently available for DM treatment include insulin, thiazolidinediones, sulfonylureas, and biguanides [5]. Although the drugs' inability to effectively control the complications (except insulin under strict glycemic management) that accompany diabetes has brought about the search for new therapeutics. 
Therefore, novel hypoglycemic agents with fewer diabetic complications are being explored to solve this health challenge. Several herbs with anti-diabetic activity reported in the literature include Aloe vera, Aloe barbadensis, Alium cepa, Phyllanthus species, Panax species, Acacia arabica, Momordica charantia [6,7].

Entandrophragma cylindricum, also called Sapele or sapelli (Meliaceae), is a hardwood timber species native to tropical Africa. The tree is about $45 \mathrm{~m}$ (rarely $60 \mathrm{~m}$ ) in height [8]. During the dry season, the leaves are deciduous, pinnate, arranged alternately, with each leaflet about $10 \mathrm{~cm}$ long. It is a heliophilous species of the canopy, hermaphrodite, and insectpollinated. The bark has been exploited as therapy for rheumatism, colds, lung complaints, bronchitis, edema. In Cameroon, it has been used to treat typhoid fever, malaria, diarrhea, stomach-ache, and yellow fever [9-11]. Phytochemical constituents of Entandrophragma cylindricum that have been reported include limonoids and highly oxygenated acyclic triterpenes [12]. This study aims to validate the anti-diabetic and antidyslipidemic activities of aqueous extract of Entandrophargma cylindricum stem on streptozotocin-induced diabetic rats.

\section{Materials and Methods}

\subsection{Collection and identification of plant extract.}

Entandrophargma cylindricum bark was obtained from herb sellers in the popular market, "Ojatuntun" in Ilorin, Kwara state Nigeria. It was identified and authenticated at the herbarium, Department of Plant Science, University of Ilorin, Nigeria. The stem bark of Entandrophargma cylindricum obtained was chopped into fragments to aid quick drying and oven-dried at $40{ }^{\circ} \mathrm{C}$ till a constant weight was obtained. The dried bark was initially grounded using mortar and pestle before using an electric blender to blend into a fine powder. The powdered sample (300 g) was soaked in $3 \mathrm{~L}$ of distilled water. The mixture was stirred and allowed to stand for forty-eight hours. The soaked sample was filtered with a muslin cloth, and the filtrate was concentrated with the aid of a vacuum evaporator. The dried extract was then reconstituted into the desired concentrations.

\subsection{Chemicals and reagents.}

Streptozotocin used was a product of Sigma Aldrich (United Kingdom). All other reagents were of analytical grade.

\subsection{Experimental animals and DM induction.}

Thirty healthy male Albino rats $(190 \pm 10 \mathrm{~g})$ were procured from the animal breeding units, Central Research Laboratory, University of Ilorin, Ilorin. Animal handling and treatment were slated by the procedure for laboratory animal care and use and the University of Ilorin Animal Ethics Committee's approval. The research adhered to the protocols for Laboratory Animal Care (NIH publication No.85-23, revised in 2004). The animal house was wellventilated, clean metabolic cages under a $12 \mathrm{~h}$ light-dark cycle at $25 \pm 2{ }^{\circ} \mathrm{C}$. For 7 days, the animals were acclimatized and fed a normal diet and water ad libitum during this period. Animals were made diabetic by a single intraperitoneal (ip) STZ administration, at $45 \mathrm{mg} / \mathrm{kg}$ bw, after fasting overnight. Fasting blood glucose (FBG) test was used to confirm hyperglycemia development in rats after $48 \mathrm{~h}$ post-streptozotocin injection. 


\subsection{Animal grouping and administration.}

The animals (30) were grouped into 6 groups of 5 each: group A (control) rats were not induced with diabetes; group B (diabetic treated with Metformin $100 \mathrm{mg} / \mathrm{kg}$ ); group C (diabetic untreated); group D (diabetic treated with Entandrophargma cylindricum extract $50 \mathrm{mg} / \mathrm{kg}$ ); group E (diabetic treated with Entandrophargma cylindricum extract $100 \mathrm{mg} / \mathrm{kg}$ ) and group F (diabetic treated with Entandrophargma cylindricum extract $200 \mathrm{mg} / \mathrm{kg}$ ). FBG (Fasting blood glucose) and GTT (glucose tolerance test) were recorded at intervals for 21 days. Then, the rats were fasted overnight and sacrificed. The blood and liver were obtained, homogenized, and centrifuged for the biochemical assays.

\subsection{Phytochemical screening.}

The phytochemical screening was done as determined by Sofowora [13] and Trease and Evans [14].

\subsection{Biochemical assays.}

Determination of blood sugar was performed using a glucometer, while the determination of plasma insulin was carried out using an insulin ELISA kit. Hexokinase activity was measured using the method of Brandstrup et al. [15]. Hepatic glucose was determined using the dinitrosalicylic (DNS) assay [16]. Hepatic glycogen level was measured as glucosyl units following acid hydrolysis [17]. Koide and Oda [18] determined the measurement of glucose-6-phosphatase level. Glucose-6-phosphate dehydrogenase activity was measured by the method of Gancedo and Gancedo [19]. The total cholesterol, HDLcholesterol, and triglyceride concentrations in the plasma were assayed by the method of Frederickson et al. [20], Albers et al. [21], and Giacco et al. [22], respectively.

\subsection{Statistical analysis.}

Data were expressed as the means \pm SEM of five determinations. Statistical analysis was done using one-way Analysis of variance (ANOVA) and Duncan Multiple Range Test (DMRT). The data were considered statistically significant at $p<0.05$.

\section{Results and Discussion}

Plants have become drug sources for several ailments or sicknesses. Practitioners of traditional medicine have utilized E. cylindricum for various ailments. The stem bark decoctions of E. cylindricum are used to treat fevers and malaria [7]. The Nigerian herb database has reported E. cylindricum to possess blood glucose-lowering effects in animal models. The phytochemical analysis of the stem bark of E. cylindricum revealed the presence of tannins, glycosides, phenolics, flavonoids, and terpenoids. These secondary metabolites may be responsible for various biological activities, including anti-diabetic. Several investigators have shown that some plants that possess polyphenolic compounds and a host of the other secondary metabolites of the plant possess hypoglycemic activities [23].

Table 1. Qualitative analysis of Entandrophargma cylindricum stems bark extract.

\begin{tabular}{l|l} 
Phytochemicals & Result \\
\hline Flavonoids & ++ \\
\hline Tannin & ++
\end{tabular}




\begin{tabular}{l|l} 
Phytochemicals & Result \\
\hline Phenol & ++ \\
\hline Alkaloids & - \\
\hline Terpenoids & ++ \\
\hline Steroids & ++ \\
\hline Glycosides & ++ \\
\hline Reducing sugar & + \\
\hline Saponin & - \\
\hline Anthraquinone & ++ \\
\hline Oil Note: $+=$ Trace,$++=$ Present,$-=$ Absent.
\end{tabular}

Table 2.Fasting blood glucose concentration of animals administered with aqueous extract of E. cylindricum stem.

\begin{tabular}{l|l|l|l|l} 
Group & Day 0 & Day 7 & Day 14 & Day 21 \\
\hline Control & $94 \pm 5.45^{\mathrm{a}}$ & $105 \pm 4.55^{\mathrm{a}}$ & $120 \pm 7.35^{\mathrm{a}}$ & $115 \pm 8.55^{\mathrm{a}}$ \\
\hline Metformin & $102 \pm 3.45^{\mathrm{a}}$ & $235 \pm 5.25^{\mathrm{b}}$ & $155 \pm 4.65^{\mathrm{a}}$ & $136 \pm 3.75^{\mathrm{a}}$ \\
\hline Diabetic untreated & $116 \pm 4.02^{\mathrm{a}}$ & $320 \pm 8.55^{\mathrm{b}}$ & $375 \pm 7.65^{\mathrm{c}}$ & $290 \pm 3.46^{\mathrm{b}}$ \\
\hline $\begin{array}{l}\text { Diabetic }+50 \mathrm{mg} / \mathrm{kg} \text { bw } \\
\text { extract }\end{array}$ & $98 \pm 4.84^{\mathrm{a}}$ & $285 \pm 3.50^{\mathrm{b}}$ & $209 \pm 2.15^{\mathrm{b}}$ & $184 \pm 2.45^{\mathrm{a}}$ \\
\hline $\begin{array}{l}\text { Diabetic }+100 \mathrm{mg} / \mathrm{kg} \text { bw } \\
\text { extract }\end{array}$ & $122 \pm 3.25^{\mathrm{a}}$ & $244 \pm 3.50^{\mathrm{b}}$ & $173 \pm 3.43^{\mathrm{a}}$ & $128 \pm 3.25^{\mathrm{a}}$ \\
\hline $\begin{array}{l}\text { Diabetic }+200 \mathrm{mg} / \mathrm{kg} \text { bw } \\
\text { extract }\end{array}$ & $125 \pm 3.15^{\mathrm{a}}$ & $246 \pm 5.23^{\mathrm{b}}$ & $163 \pm 3.45^{\mathrm{a}}$ & $106 \pm 4.55^{\mathrm{a}}$
\end{tabular}

Values are presented as means $(n=5) \pm$ S.E.M. Values with different superscript are significant at $p<0.05$ versus control.

Pancreatic $\beta$-cells are responsible for insulin production. STZ induces diabetes in animals by destroying pancreatic- $\beta$-cells. Deficiency or massive reduction in insulin may cause hyperglycemia, which insulin only can reverse [24]. Fasting blood glucose concentrations after administration with aqueous extract of E. cylindricum stem bark at day 0, day 7, day 14, day 21 in animals are shown in Table 2. The high glucose values in diabetic rats were reduced on day 7 , but it was reversed near normal compared with the non-diabetic group on day 14, day 21 . The results indicated that E. cylindricum stem bark significantly reduced the blood glucose level of diabetic rats. Other plant studies have also been reported to reduce the fasting blood glucose level of diabetic rats [25-27]. The observed reduction in the fasting blood glucose level may be attributed to high phenolics, a secondary metabolite found in the extract [26]. The results also showed that postprandial glucose reduction in the animals might have been associated with reduced glucogenic activity with decreased excretion of urea or glycogenolysis inhibition as suggested by liver glycogen increase [28].

Glucose tolerance response in streptozotocin-induced diabetic albino male rats administered with aqueous extract of E. cylindricum stem at $0 \mathrm{~min}, 15 \mathrm{~min}, 30 \mathrm{~min}, 60 \mathrm{~min}$, and 90 min after 7 days, 14 days, and 21 days was shown in figure 1.

The treated groups of Entandrophargma cylindricum extract have a high blood glucose level (mg/dl) compared to the non-diabetic group (untreated) after 7 days. However, the treated groups have their blood glucose level $(\mathrm{mg} / \mathrm{dl})$ normal compared to the non-diabetic group (untreated) on the 14th day and 21st day.

Hexokinase activity of animals administered with aqueous extract of E. cylindricum stem bark showed a significant $(p<0.05)$ increase in the metformin and $200 \mathrm{mg} / \mathrm{kg}$ bw compared with the control group, as shown in Figure 2a. Significant increase in hexokinase activity in the group administered with $200 \mathrm{mg} / \mathrm{kg}$ bw E. cylindricum. This enzyme is located 
in the glycolytic pathway. It converts glucose to glucose 6 phosphate with the use of ATP. This enzyme was boosted in diabetic rats following E. cylindricum stem bark administration.

Plasma insulin concentration of animals administered with aqueous extract of $E$. cylindricum stem showed a significant $(p>0.05)$ decrease in the untreated group 50 and 100 $\mathrm{mg} / \mathrm{kg}$ bw of the extract as shown in figure $2 \mathrm{~b}$. Plasma insulin concentration significantly decreases in the untreated group and $50 \mathrm{mg} / \mathrm{kg}$ bw and $100 \mathrm{mg} / \mathrm{kg}$ bw E. cylindricum. Serum insulin concentration is responsible for the conversion of excess glucose to glycogen. The reduction in insulin concentration reduces glycogen conversion, thereby making the glucose more available to the cell.

Glucose concentration in the liver of animals administered with aqueous extract of $E$. cylindricum stem bark showed a significant $(p<0.05)$ decrease in the untreated group, while a significant increase was observed in the metformin group (Figure 3a). Hepatic glycogen levels significantly $(p<0.05)$ decrease at 50 and $100 \mathrm{mg}$ bw of the extract-treated group (Figure $3 \mathrm{~b}$ ).

Plasma glucose-6-phosphatase concentration of animals administered with aqueous extract of E. cylindricum stem showed no significant changes across all groups compared with the control (Figure 4a). Hepatic glucose 6 phosphate dehydrogenase activity in the animals administered with aqueous extract of E. cylindricum stem showed a significant $(p<0.05)$ increase in the group treated with metformin. The untreated group had a significant decrease compared with the control group, as shown in Figure 4b. The observed increase in glucose-6phosphatase activity in the group treated with metformin and $50 \mathrm{mg} / \mathrm{kg}$ bw E. cylindricum compared with the non-diabetic group was noted. This enzyme is located in the gluconeogenesis pathway, a metabolic pathway that produces glucose from non-glucose metabolites. It converts glucose-6-phosphate back to glucose [29]. This enzyme was significantly increased, hence increasing its activities.

Several studies have reported that a rise in serum lipids such as TC and triacylglycerols could suggest the induction of diabetes due to changes in lipid metabolism [30]. The aberrations in cellular cholesterol metabolism could alter the serum cholesterol levels in diabetic patients and oxidative stress, associated with increased lipid accumulation in the cells [31]. The anomalies in the metabolism of lipids in diabetic conditions lead to variations in serum lipids and lipoproteins, which in turn causes severe atherosclerosis that affects diabetic patients [32]. Measurements of these parameters are essential to avert cardiac complications in diabetic conditions [32]. The major distinctive features of diabetic dyslipidemia are high serum triacylglycerol concentration and low-density lipoprotein cholesterol with corresponding low high-density lipoprotein cholesterol [33]. There is a need for therapeutic agents with both antidiabetic and anti-obese effects of immense potential benefit. The aqueous extract of $E$. cylindricum stem bark may serve these benefits. Cholesterol concentration in the plasma of animals administered with aqueous extract of E. cylindricum stem showed a significant $(p<$ 0.05 ) increase in the untreated group compared with the control group, as shown in Figure 5a. Plasma high-density lipoprotein concentration in the animals administered with aqueous extract of E. cylindricum stem significantly $(p<0.05)$ decreased in the untreated group, 50 and $100 \mathrm{mg} / \mathrm{kg}$ bw of the extract as shown in Figure 5b. Triglycerides concentration in the plasma of animals administered with aqueous extract of E. cylindricum stem bark showed no significant changes (Figure 5c). The metformin administration and the aqueous extract $E$. cylindricum stem bark led to a drop in total cholesterol and triacylglycerol with a corresponding increase in High-density lipoprotein. Therefore, the aqueous E. cylindricum stem bark extract 
shows that it may control lipid metabolism and avert the upsurge of coronary artery disease and atherosclerosis.
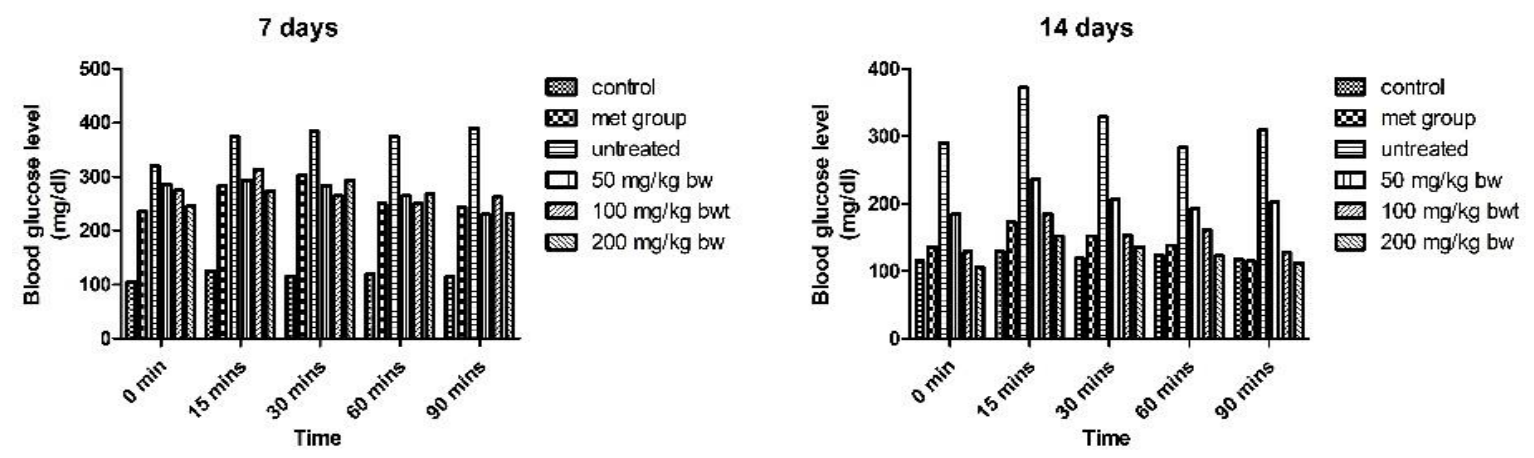

21 days

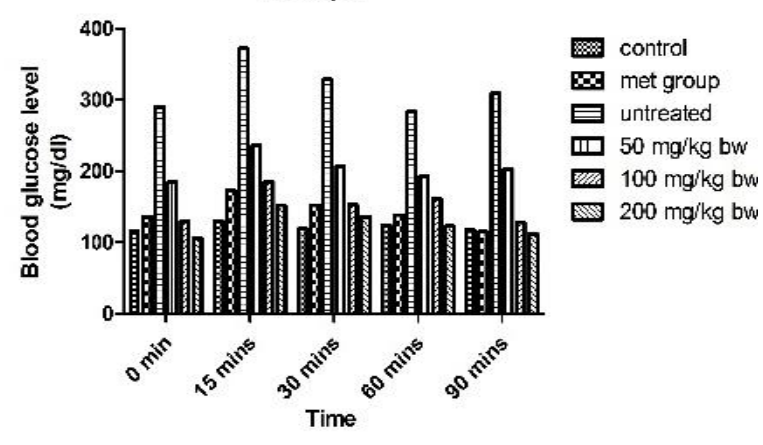

Figure 1. Glucose tolerance response in the blood after administering an aqueous extract of $E$. cylindricum stem after 7 days, 14 days, and 21 days of treatment.
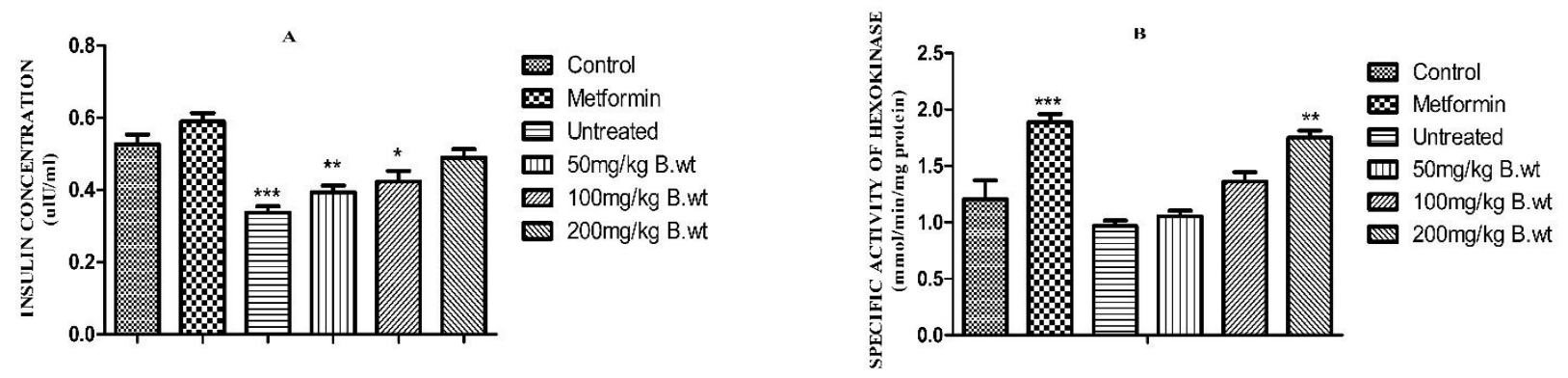

Figure 2. (A) Plasma insulin concentration; (B) hexokinase activity of animals administered with aqueous extract of E. cylindricum stem. Values are presented as means $($ n=5) \pm S.E.M. Values with different superscript are significant at $p<0.05$ versus control.
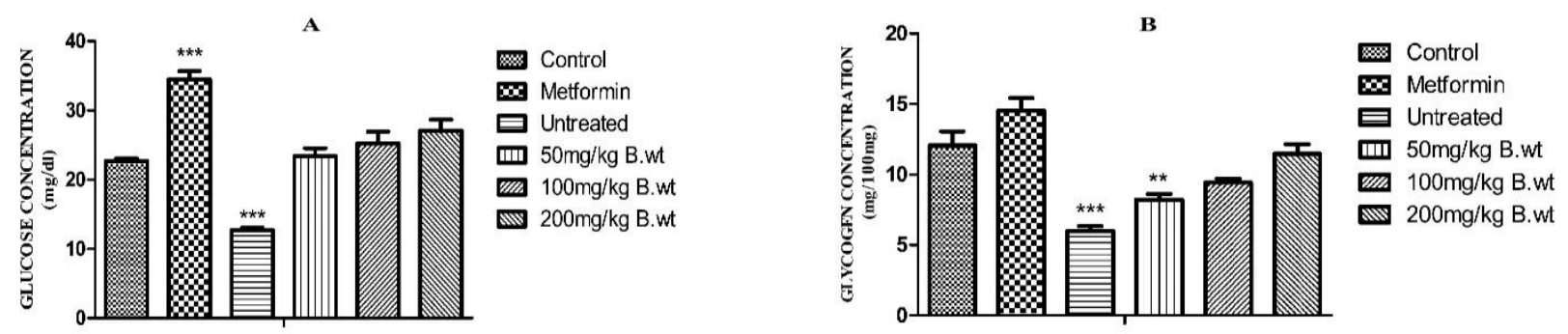

Figure 3. (A) Glucose concentration; (B) glycogen concentration in the liver of animals administered with aqueous extract of E. cylindricum stem. Values are presented as means $(\mathrm{n}=5) \pm$ S.E.M. Values with different superscript are significant at $p<0.05$ versus control. 

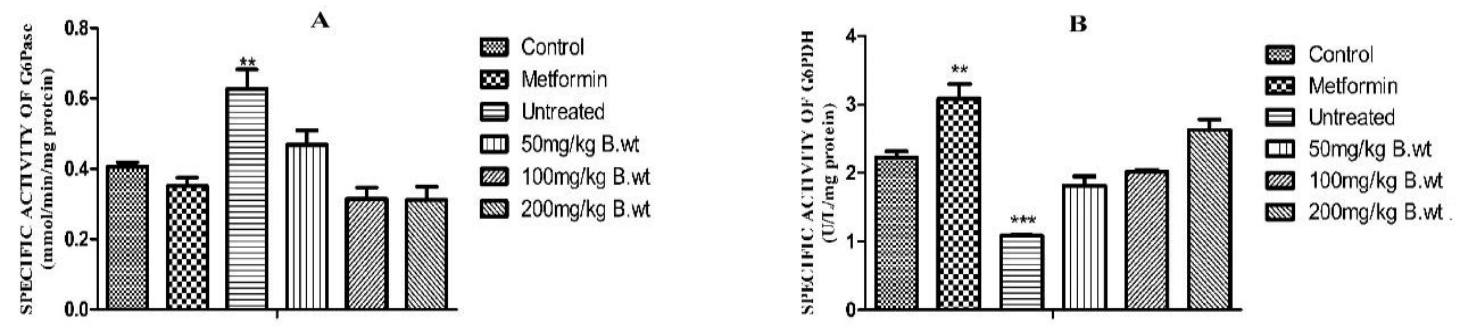

Figure 4. (A) Plasma glucose-6-phosphatase concentration; (B) Glucose 6 phosphate dehydrogenase activity in the liver of animals administered with aqueous extract of E. cylindricum stem. Values are presented as means $(\mathrm{n}=5) \pm$ S.E.M. Values with different superscript are significant at $p<0.05$ versus control.
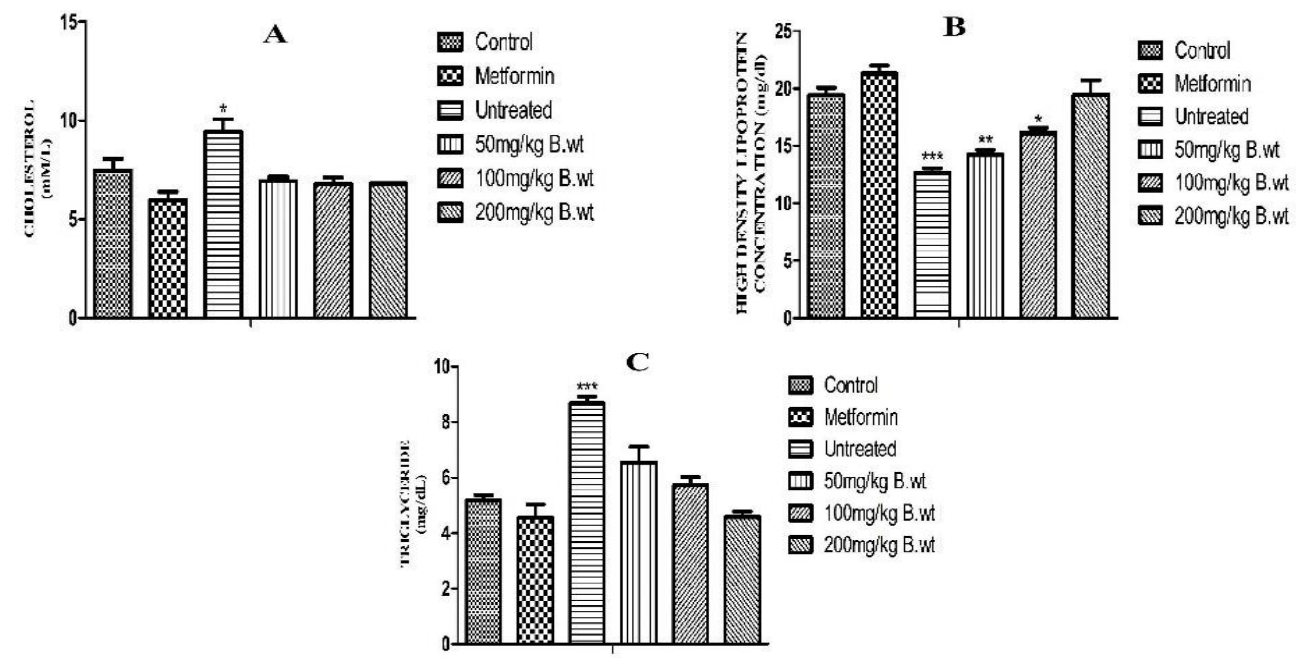

Figure 5. (A) Cholesterol concentration; (B) high-density lipoprotein concentration; (C) triglycerides concentration in the plasma of animals administered with aqueous extract of E. cylindricum stem. Values are presented as means $(n=5) \pm$ S.E.M. Values with different superscript are significant at $p<0.05$ versus control.

\section{Conclusions}

Overall, we can suggest that the aqueous extract of E. cylindricum stem bark possesses significant anti-diabetic and antidyslipidemic activity in diabetic rats as it regulates lipid metabolism

\section{Funding}

This study had no external funding.

\section{Acknowledgments}

This research has no acknowledgment.

\section{Conflicts of Interest}

The authors declare no conflict of interest.

\section{References}

1. Karigidi, K.O.; Akintimehin, E.S.; Omoboyowa, D.A.; Adetuyi, F.O.; Olaiya, C.O. Effect of Curculigo pilosa supplemented diet on blood sugar, lipid metabolism, hepatic oxidative stress and carbohydrate metabolism enzymes in streptozotocin-induced diabetic rats. Journal of Diabetes \& Metabolic Disorders 2020, 19, 11731184, https://doi.org/10.1007/s40200-020-00618-w. 
2. Bichard, L.K.; Torpy, D.J. Diabetes insipidus complicating apoplexy during pregnancy: the potential use of copeptin. Internal Medicine Journal 2020, 50, 877-879, https://doi.org/10.1111/imj.14918.

3. Kou, H.; Deng, J.; Gao, D.; Song, A.; Han, Z.; Wei, J.; Jin, X.; Ma, R.; Zheng, Q. Relationship among adiponectin, insulin resistance and atherosclerosis in non-diabetic hypertensive patients and healthy adults. $\begin{array}{lllll}\text { Clinical and } \quad \text { Experimental } & \text { Hypertension }\end{array}$ https://doi.org/10.1080/10641963.2018.1425414.

4. Giri, B.; Dey, S.; Das, T.; Sarkar, M.; Banerjee, J.; Dash, S.K. Chronic hyperglycemia mediated physiological alteration and metabolic distortion leads to organ dysfunction, infection, cancer progression and other pathophysiological consequences: An update on glucose toxicity. Biomedicine \& Pharmacotherapy 2018, 107, 306-328, https://doi.org/10.1016/j.biopha.2018.07.157.

5. Padhi, S.; Nayak, A.K.; Behera, A. Type II diabetes mellitus: a review on recent drug based therapeutics. Biomedicine \& Pharmacotherapy 2020, 131, 110708, https://doi.org/10.1016/j.biopha.2020.110708.

6. Pereira, A.S.P.; Banegas-Luna, A.J.; Peña-García, J.; Pérez-Sánchez, H.; Apostolides, Z. Evaluation of the Anti-Diabetic Activity of Some Common Herbs and Spices: Providing New Insights with Inverse Virtual Screening. Molecules 2019, 24, https://doi.org/10.3390/molecules24224030.

7. Tran, N.; Pham, B.; Le, L. Bioactive Compounds in Anti-Diabetic Plants: From Herbal Medicine to Modern Drug Discovery. Biology 2020, 9, https://doi.org/10.3390/biology9090252.

8. Mokale Kognou, A.L.; Kopa Kowa, T.; Pateriya, P.; Narayan Pal, P.; Mouokeu, R.S.; Tchinda Tiabou, A.; Agbor Agbor, G.; Pawar Singh, R.; Ngono Ngane, R.A. Pharmacological evidence of Vitex thyrsiflora, Entandrophragma cylindricum, and Anonidium mannii used for the management of inflammation in Cameroon. Journal of Basic and Clinical Physiology and Pharmacology 2020, 31, https://doi.org/10.1515/jbcpp-2019-0053.

9. Jain, S.; Vaidya, A.; Shah, K.; Chauhan, D.N.; Chauhan, N.S. Anti-sickling Herbs. In Plant and Human Health, Volume 3: Pharmacology and Therapeutic Uses, Ozturk, M., Hakeem, K.R., Eds. Springer International Publishing: Cham, 2019; https://doi.org/10.1007/978-3-030-04408-4_12.

10. Happi, G.M.; Mouthe Kemayou, G.P.; Stammler, H.-G.; Neumann, B.; Ismail, M.; Kouam, S.F.; Wansi, J.D.; Tchouankeu, J.C.; Frese, M.; Lenta, B.N.; Sewald, N. Three phragmalin-type limonoids orthoesters and the structure of odoratone isolated from the bark of Entandrophragma candollei (Meliaceae). Phytochemistry 2021, 181, 112537, https://doi.org/10.1016/j.phytochem.2020.112537.

11. Ouédraogo, D.-Y.; Hardy, O.J.; Doucet, J.-L.; Janssens, S.B.; Wieringa, J.J.; Stoffelen, P.; Angoboy Ilondea, B.; Baya, F.; Beeckman, H.; Daïnou, K.; Dubiez, E.; Gourlet-Fleury, S.; Fayolle, A. Latitudinal shift in the timing of flowering of tree species across tropical Africa: insights from field observations and herbarium collections. J. Trop. Ecol. 2020, 36, 159-173, https://doi.org/10.1017/S0266467420000103.

12. Happi, G.M.; Wouamba, S.C.N.; Ismail, M.; Kouam, S.F.; Frese, M.; Lenta, B.N.; Sewald, N. Ergostanetype steroids from the Cameroonian 'white tiama' Entandrophragma angolense. Steroids 2020, 156, 108584, https://doi.org/10.1016/j.steroids.2020.108584.

13. Sofowora, A. Medicinal plants and traditional medicine in Africa. Nigeria. Spectrum Book Ltd 1993, 195238.

14. Akpor, O.; Olaolu, T.; Rotimi, D. Antibacterial and antioxidant potentials of leave extracts of Helianthus annuus. Potravinarstvo Slovak Journal of Food Sciences, 2019, 13(1), pp.1026-1033.

15. Brandstrup, N.; Kirk, J.E.; Bruni, C. The hexokinase and phosphoglucoisomerase activities of aortic and pulmonary artery tissue in individuals of various ages. J. Gerontol. 1957, 12, 166-171, https://doi.org/10.1093/geronj/12.2.166.

16. Shu, X.; Liu, X.M.; Liang, Q.X. Spectrophotometric determination of total and reducing sugars in star anise residue with 3, 5-dinitrosalicylic acid as color reagent. Science and Technology of Food Industry, 2010, 6.

17. Passonneau, J.V.; Lauderdale, V.R. A comparison of three methods of glycogen measurement in tissues. Anal. Biochem. 1974, 60, 405-412.

18. Koide, H.; Oda, T. Pathological occurrence of glucose-6-phosphatase in serum in liver diseases. Clin. Chim. Acta 1959, 4, 554-561, https://doi.org/10.1016/0009-8981(59)90165-2.

19. Gancedo, J.M.; Gancedo, C. Fructose-1,6-diphosphatase, phosphofructokinase and glucose-6-phosphate dehydrogenase from fermenting and non fermenting yeasts. Arch. Mikrobiol. 1971, 76, 132-138, https://doi.org/10.1007/BF00411787.

20. Fredrickson, D.S.; Levy, R.L.; Lees, R.S. Monoreagent enzymatic cholesterol. New Engl. J. Med. 1967, 276, 148-156. 
21. Warnick, G.R.; Albers, J.J. A comprehensive evaluation of the heparin-manganese precipitation procedure for estimating high density lipoprotein cholesterol. Journal of Lipid Research, 1978, 19(1), pp.65-76.

22. Giacco, R.; Costabile, G.; Della Pepa, G.; Anniballi, G.; Griffo, E.; Mangione, A.; Cipriano, P.; Viscovo, D.; Clemente, G.; Landberg, R.; Pacini, G.; Rivellese, A.A.; Riccardi, G. A whole-grain cereal-based diet lowers postprandial plasma insulin and triglyceride levels in individuals with metabolic syndrome. Nutr. Metab. Cardiovasc. Dis. 2014, 24, 837-844, https://doi.org/10.1016/j.numecd.2014.01.007.

23. Saatov, T.; Mustafakulov, M.; Ishanhodjaev, T.; Ibragimova, E. Study on hypoglycemic effect of polyphenolic compounds isolated from the Euphorbia L. plants growing in uzbekistan. In 22nd European Congress of Endocrinology 2020, 70, https://doi.org/10.1530/endoabs.70.AEP463.

24. Oleson, B.J.; Corbett, J.A. Can insulin secreting pancreatic $\beta$-cells provide novel insights into the metabolic regulation of the DNA damage response? Biochem. Pharmacol. 2020, 176, 113907, https://doi.org/10.1016/j.bcp.2020.113907.

25. Furman, B.L.; Candasamy, M.; Bhattamisra, S.K.; Veettil, S.K. Reduction of blood glucose by plant extracts and their use in the treatment of diabetes mellitus; discrepancies in effectiveness between animal and human studies. J. Ethnopharmacol. 2020, 247, 112264, https://doi.org/10.1016/j.jep.2019.112264.

26. Hamida, S.; Kawsar, A.; Sayed Yousof, M. Effect of Afghan Senjed (Elaeagnus Angustifolia L.) Leaves Aqueous alcoholic Extract on Blood Glucose Level of Diabetic Rats. Pharmacognosy Journal 2020, 12, https://doi.org/10.5530/pj.2020.12.170.

27. Nazir, N.; Zahoor, M.; Ullah, R.; Ezzeldin, E.; Mostafa, G.A.E. Curative Effect of Catechin Isolated from Elaeagnus Umbellata Thunb. Berries for Diabetes and Related Complications in Streptozotocin-Induced Diabetic Rats Model. Molecules 2021, 26, https://doi.org/10.3390/molecules26010137.

28. Hou, B.-Y.; Zhao, Y.-R.; Ma, P.; Xu, C.-Y.; He, P.; Yang, X.-Y.; Zhang, L.; Qiang, G.-F.; Du, G.-H. Hypoglycemic activity of puerarin through modulation of oxidative stress and mitochondrial function via AMPK. Chinese Journal of Natural Medicines 2020, 18, 818-826, https://doi.org/10.1016/S18755364(20)60022-X.

29. Temel, Y.; Ayna, A.; Hamdi Shafeeq, I.; Ciftci, M. In vitro effects of some antibiotics on glucose-6-phosphate dehydrogenase from rat (Rattus norvegicus) erythrocyte. Drug Chem. Toxicol. 2020, 43, 219-223, https://doi.org/10.1080/01480545.2018.1481083.

30. Kulas, J.A.; Weigel, T.K.; Ferris, H.A. Insulin resistance and impaired lipid metabolism as a potential link between diabetes and Alzheimer's disease. Drug Dev. Res. 2020, 81, 194-205, https://doi.org/10.1002/ddr.21643.

31. Aydın, S.; Bacanlı, M.; Anlar, H.G.; Çal, T.; Arı, N.; Ündeğer Bucurgat, Ü.; Başaran, A.A.; Başaran, N. Preventive role of Pycnogenol ${ }^{\circledR}$ against the hyperglycemia-induced oxidative stress and DNA damage in diabetic rats. Food Chem. Toxicol. 2019, 124, 54-63, https://doi.org/10.1016/j.fct.2018.11.038.

32. Wen, J.; Huang, Y.; Lu, Y.; Yuan, H. Associations of non-high-density lipoprotein cholesterol, triglycerides and the total cholesterol/HDL-c ratio with arterial stiffness independent of low-density lipoprotein cholesterol in a Chinese population. Hypertens. Res. 2019, 42, 1223-1230, https://doi.org/10.1038/s41440-019-0251-5.

33. Vergès, B. Dyslipidemia in type 1 diabetes: a masked danger. Trends Endocrinol. Metab. 2020, 31, 422-434, https://doi.org/10.1016/j.tem.2020.01.015. 